\title{
Burnout and Associated Factors Among Nurses Working in A Mental Health Hospital, Madinah, Saudi Arabia
}

\author{
${ }^{1}$ Razan Essa Alsayed, ${ }^{2}$ Sami Abdo Radman Al-Dubai, ${ }^{3}$ Hanan Mosleh Ibrahim \\ ${ }^{1}$ Joint program of Community medicine, Al-Madinah, SA. ${ }^{2}$ Joint program of family \\ medicine, Post graduate studies, Al-Madinah, Al Madinah Al, SA. Joint program of \\ Preventive medicine, Post graduate studies, Al-Madinah, SA. ${ }^{3}$ Department of Family and \\ Community Medicine, Taibah University, Medina, SA. Associate professor of public \\ health and community medicine, Cairo University, Egypt
}

Submission Date: 2020-10-04 Revision Date: 2020-10-18 Acceptance Date: 2020-10-18

\begin{abstract}
Background: Burnout syndrome (BS) is a significant health problem among health care professionals (HCP). Objectives: to assess the levels of burnout dimensions among mental health care nurses in a city in the western region, Saudi Arabia, and to investigate the associated socio-demographic and work-related factors. Method: A cross-sectional study was carried out among 142 nurses in a public mental hospital in a city in the western region, Saudi Arabia during the year 2018. Data collection was based on self-administered questionnaire including data about nurses' socio-demographic and work-related factors. The assessment of BS dimensions (emotional exhaustion (EE), depersonalization (DP) and personal accomplishment (PA) was done using Maslach Burnout Inventory-Human Service Survey (MBI-HSS) instrument. Results: Low, moderate, and high levels EE were found among $43 \%, 25.4 \%$, and $31.6 \%$ of the nurses, respectively. Low level of DP was found in $70 \%$, whereas moderate and high levels of DP were found in $14.5 \%$ and $15.5 \%$ of the nurses respectively. Low, moderate and high levels of PA were found in 38\%, $15.5 \%$ and $46.5 \%$ of nurses respectively. BS was found to be associated with nurses' sex (EE) and working $\leq 8$ hours/day (PA). Conclusion Low to moderate level of self-reported burnout among the mental health nurses was found. Work duration was found to play a role in personal accomplishment subscale of burnout.
\end{abstract}

Keywords: Burnout syndrome, nurses, mental health

Corresponding author: Hanan Mosleh Ibrahim Email :Hananmosleh@hotmail.com

\section{Introduction}

Burnout has been noted as a significant problem among different, active working populations worldwide. It is defined as " $\mathrm{A}$ psychological syndrome emerging as a prolonged response to chronic interpersonal stressors on the job". ${ }^{1}$ Three critical dimensions of burnout syndrome are described; emotional exhaustion dimension (EE) indicating wearing out, emotional depletion and fatigue, and depersonalization (DP) dimension indicating the negative attitudes towards The Egyptian Journal of Community Medicine clients and reduced involvement in their work. Lastly, personal accomplishment (PA) which identifies the sense of ineffectiveness and low morale as well as reduced productivity and an inability to cope. $^{1,2,3}$

Burnout is common among healthcare professionals. $^{3}$ Nursing profession is extremely stressful as the nurses deal with the human (or affective) aspects in addition to medical aspects of health and illness in order to provide ongoing regular

$\begin{array}{llll}\text { Vol. } 39 & \text { No. } 3 & \text { July } & 2021\end{array}$


emotional and physical care and deliver the highest percentage of patient care. ${ }^{4}$ Thus, nurses are extremely vulnerable to burnout ${ }^{4,8,9}$ due to many stressors such as staff shortage, the demanding patient, workload, inadequate resources, and organizational factors. Consequently, mental healthcare staff also reported higher rates of burnout than HCPs in other sectors. ${ }^{1,10}$ Notably, nurses working in mental healthcare have a higher level of stress and burnout than other nurses. ${ }^{11,12}$ Besides regular experienced stress, researches has identified some of the unique stressors that mental health professionals face when they are dealing with difficult or violent clients compared to their colleagues in other fields. ${ }^{1,10,13}$

Several demographic and work-related variables have been studied concerning burnout among nurses. Age is one variable that shows a more consistent correlation with burnout. In a metaanalysis of 51 studies, the dimensions of $\mathrm{EE}$ and DP were higher in younger nurses than older ones. ${ }^{14}$ Gender as a demographic variable has not been a strong predictor of burnout; some studies demonstrated that males report a higher level of burnout while others indicated females as more vulnerable to developing such emotional distress. ${ }^{9}$ The small but consistent sex difference was demonstrated as males often score slightly higher on DP while women score slightly higher EE. ${ }^{6}$

Regarding outcomes, job burnout can lead to severe consequences for the workers, their clients, and families; their work environment; and the organizations. ${ }^{8,10}$ In the health sector, high burnout level can lead to deterioration in the quality of care or services provided by the staff, which may in turn lead to undesirable patient safety outcomes. ${ }^{15}$ Moreover, it can result in poor work performance and job dissatisfaction as well as higher absenteeism and staff turnover. ${ }^{10,16}$ In addition to their job implication, burnout can also affect the workers' health. Studies have shown associations between the burnout and some health problems such as smoking ${ }^{17}$ alcohol consumption $^{18}$, sleep disturbance ${ }^{19}$ and increased risk of musculoskeletal pain. ${ }^{20}$ Currently, burnout is frequently linked with some psychological disorders such as depression and anxiety. ${ }^{1}$

The current study aims to improve the general well-being among nurses working in mental healthcare, and to raise the awareness and knowledge about health professional burnout among healthcare workers

Objectives: To measure the burnout levels among nurses working in a public mental hospital in Madinah city, Saudi Arabia and to assess the association between certain socio-demographic and work-related factors with burnout syndrome among them.

\section{Method}

Study design: This is a cross-sectional study design. Study setting and study period: The study was conducted in a public mental hospital affiliated to the Ministry of Health $(\mathrm{MOH})$ in Madinah, Saudi Arabia. It includes emergency room and intensive care unit, outpatient facility, radiology and laboratories departments, and pharmaceutical services. Besides, there are eight villas for hospitalization for mental health and de-addiction care, two entertainment centers and other facilities.

The majority of nurses working in the setting are Saudis (83.3\%), $76.1 \%$ are males, $10.1 \%$ are nurse-assistants. The total bed capacity of the complex is 246 beds and the current nurse-to-patient ratio for day shift in all wards is one nurse per six patients (1:6).

OpenEpi program ${ }^{21}$ was used to calculate the sample size. The sample was calculated using the estimated frequency of burnout among Saudi critical nurses, of $84 \%$, reported in a recent Saudi study ${ }^{22}$, 
an accepted error of 5\%, confidence limit of $95 \%$, and a statistical power of $80 \%$. This yielded a sample size of at least 207 nurses.

A non-probability sampling procedure was used in this study. The target population were all nurses working in the selected mental hospital. Inclusion criteria involved being of any gender, any nationality, speaking Arabic or English, and working for at least one year in the mental hospital. Exclusion criteria included those working exclusively in non-nursing duties such as administrative or educational roles; those on annual vacations, sick leave, or maternity leave; and students and interns who were in training within the hospital. All eligible nurses found in the hospital while conducting the study were invited to participate in the study. Of a total of 277 nurses working in the setting at the time of the study, 41 had exclusion criteria. Thus, a total of 226 nurses were available for the study. Of these, 142 filled and returned back the self-administered questionnaire (response rate of $62.83 \%$ )

Data were collected using a structured self-administered questionnaire in either Arabic or English languages according to the participant's preference. The questionnaire included three sections; and the first and second sections included demographic and work-related data respectively. Demographic data included age, sex, nationality, marital status, having of children, income, qualification; work-related data included job title, working unit, working hours per day, currently having night shifts and currently working during weekends.

The third section of the study questionnaire included the Maslach Burnout Inventory-Human Service Survey (MBI-HSS) ${ }^{23,} 24$ which was used to assess burnout level among participants. The Cronbach's alpha of the English version of this inventory was 0.90 for EE, 0.76 for DP, and 0.76 for PA. ${ }^{24}$
The Arabic version of this inventory used in this study was validated and recorded with a Cronbach's alpha for the three subscales being: 0.88 for $\mathrm{EE}, 0.78$ for $\mathrm{DP}$, and 0.89 for PA. ${ }^{5}$ The scale has 22 -items designed to describe the three main aspects burnout namely; EE, DP, and PA. Each item is answered on a seven-point Likert scale of 0-7. Responses are summed to give independent scores for each of the three subscales, which can then be categorized as low, average, or high degrees of burnout according to normative data based on established cutoff scores $(25,26)$. For EE subscale, a score $\leq 18,19-26, \geq 27$ indicated low, average and high EE respectively. For DP subscale, a score $\leq 5,6-9, \geq 10$ indicated low, average and High DP respectively. For PA subscale, a score $\geq 40,39-34, \leq 33$ indicated low, average and high PA respectively (26). Thus, burnout would be indicated by high scores for EE and DP, and low scores for PA.

\section{Statistical analysis:}

Data were entered and analyzed using the Statistical Package of the Social Scientists (SPSS) for Windows, Student Version 23.0, (SPSS, Chicago, Illinois, USA) with statistical significance set at $\mathrm{p}<0.05$. First, Shapiro-Wilk's test was applied to evaluate whether continuous variables were normally distributed. Descriptive statistics were utilized to describe the sample characteristics in the form of median (with minimum and maximum values) or mean \pm SD for all continuous data. For categorical data, frequency, number, and percentage were used to describe sample characteristics.

Univariate analysis using $\chi^{2}$ or Fisher's exact test, as was appropriate was performed to investigate association of certain sociodemographic and workrelated factors with (MBI-HSS scales).

\section{Ethical considerations}

An ethical approval was obtained from the General Directorate of Health Affairs in 
Madinah and Institutional Review Board Committee. All participants gave informed consent prior to participation, Table 1: Sociodemographic and Workrelated Characteristics of The Participants (N=142)

\begin{tabular}{|c|c|}
\hline Characteristics & $\mathbf{N}(\%)$ \\
\hline \multicolumn{2}{|l|}{ Age (years) } \\
\hline $25-29$ & $29(20.4)$ \\
\hline $30-34$ & $46(32.4)$ \\
\hline $35-39$ & $44(31.0)$ \\
\hline $40-44$ & $13(9.2)$ \\
\hline $45-49$ & $5(3.5)$ \\
\hline $50+$ & $5(3.5)$ \\
\hline \multicolumn{2}{|l|}{ Gender } \\
\hline Male & $98(69.0)$ \\
\hline female & $44(31.0)$ \\
\hline \multicolumn{2}{|l|}{ Nationality } \\
\hline Saudi & $129(90.8)$ \\
\hline Non-Saudi & $13(9.2)$ \\
\hline \multicolumn{2}{|l|}{ Qualification } \\
\hline Diploma & $99(69.7)$ \\
\hline Bachelor & $42(29.6)$ \\
\hline Master & $1(0.7)$ \\
\hline \multicolumn{2}{|l|}{ Marital status } \\
\hline Single & $24(16.9)$ \\
\hline Married & $112(78.9)$ \\
\hline Divorced & $5(3.5)$ \\
\hline widowed & $1(0.7)$ \\
\hline \multicolumn{2}{|l|}{ Having children } \\
\hline Yes & $106(74.6)$ \\
\hline No & $36(25.4)$ \\
\hline \multicolumn{2}{|l|}{$\begin{array}{l}\text { Basic salary } \\
\text { (SR/month) }\end{array}$} \\
\hline Less than 5000 & $6(4.2)$ \\
\hline $5000-10000$ & $44(31.0)$ \\
\hline More than 10000 & $92(64.8)$ \\
\hline \multicolumn{2}{|l|}{ Job title } \\
\hline Nurse & $137(96.5)$ \\
\hline Nurse assistant & $5(3.5$ \\
\hline \multicolumn{2}{|l|}{$\begin{array}{l}\text { Current working } \\
\text { unit }\end{array}$} \\
\hline ER and ICU & $17(12.0)$ \\
\hline Inpatient care & $78(54.9)$ \\
\hline Outpatient care & $19(13.4)$ \\
\hline Forensic care & $6(4.2)$ \\
\hline Others & $22(15.5)$ \\
\hline \multicolumn{2}{|l|}{$\begin{array}{ll}\text { Currently } & \text { having } \\
\text { night shift } & \end{array}$} \\
\hline Yes & $73(51.4)$ \\
\hline No & $69(48.6)$ \\
\hline $\begin{array}{l}\text { Currently working } \\
\text { at weekend }\end{array}$ & $82(57.7)$ \\
\hline
\end{tabular}

\begin{tabular}{ll}
\hline Yes & $60(42.3)$ \\
No & \\
\hline
\end{tabular}

and their anonymity was preserved, and they were guaranteed confidentiality and that the questionnaires were coded without identifying their identity.

\section{Results}

Table 1 shows that $63.4 \%$ of the participants were within (30-39) age group, mostly Saudi nationality (90\%), and males $(69 \%)$. Most of the nurses were married (79\%), having children $(74.6 \%)$ and of that $37.6 \%$ have four or more children. Sixty-four percent reported that their basic salary is more than 10000 SR per month. As regards work-related characteristics; $69.7 \%$ had a nursing diploma, $50.1 \%$ reported currently spending $\geq 8$ hours daily in the hospital. Most nurses worked in the inpatient wards $(54.9 \%), 51 \%$ reported that they are currently working at night, and $58.5 \%$ reported that they are currently working during the weekend.

Table 2 shows that $31.6 \%$ and $25.4 \%$ of the participants have high and moderate EE levels respectively. whereas low, moderate and high levels of DP were found in $70.4 \%, 14.5 \%$ and $15.5 \%$ of the participants respectively. Low level of PA was found in $38 \%$ of the participants while moderate and high levels of PA were found in $15.5 \%$ and $46.5 \%$ of them respectively.

Table 3 shows that males are significantly less likely to have emotional exhaustion compared with female nurses $(\mathrm{p}=0.031)$. None of the studied factors is statistically significant with EE. For depersonalization, none of the studied factors have been found to be associated with this subscale, as all factors revealed a statistically non-significant difference $(\mathrm{p}<0.05)$. However, the risk was found to increase among Saudi nurses $(\mathrm{OR}=2.47)$ 
insignificantly, and to decrease among nurses working $\leq 8$ hours insignificantly

(Table 4).
Table 5 shows that nurses who work eight hours or less per day were more likely to have diminished personal 142)

\begin{tabular}{lccrrr}
\hline \multirow{2}{*}{$\begin{array}{c}\text { MBI } \\
\text { subscales }\end{array}$} & \multirow{2}{*}{$\begin{array}{c}\text { Mean score } \\
\mathbf{\pm} \text { SD }\end{array}$} & $\begin{array}{c}\text { Median score } \\
(\text { min-max })\end{array}$ & \multicolumn{1}{c}{ Low } & Moderate & \multicolumn{1}{c}{ High } \\
\hline EE & $21.2 \pm 12.8$ & $22(0-54)$ & $61(43.0)$ & $36(25.4)$ & $45(31.6)$ \\
DP & $4.1 \pm 5.1$ & $2(0-24)$ & $100(70.4)$ & $2(14.1)$ & $22(15.5)$ \\
PA & $34.9 \pm 11.5$ & $38(0-48)$ & $54(38)$ & $22(15.5)$ & $66(46.5)$ \\
\hline
\end{tabular}

accomplishment in comparison to those who work more than eight hours per day $(\mathrm{OR}=2.381,95 \% \mathrm{CI}=1.211-4.679$, $\mathrm{p}=0.011$ ). However, neither gender, nationality, having children, job title, working in night shifts nor the days of working during weekends were statistically significant to be associated with personal accomplishment.

\section{Discussion}

The study findings revealed $25.4 \%$, and $31.6 \%$ of participants have moderate, and high levels of EE, respectively. Low level of DP was found in 70\%, low level of PA was found in $38 \%$ of the studied sample. Many studies indicated that the level of burnout vary among different nursing specialties, and nurses who work in psychiatric care are more prone to burnout. $^{27}$ A much higher level of burnout, however, was reported in previous Saudi studies. A cross sectional study was conducted among 200 nurses in Tabouk military hospital and reported that $75.9 \%$ of the studied nurses have BS. ${ }^{25}$ Another cross-sectional study carried out in five hospitals, reported nearly three quarters of the studied nurses had high burnout level. ${ }^{28}$ Similarly, another study was conducted in intensive care units on 150 nurses has reported a moderate to high level of burnout among Saudi national critical care nurses. ${ }^{29}$ Although no studies were conducted in mental health care centers, the findings of previous studies revealed burnout is a common among nurses in Saudi Arabia. The present study has presented the level of burnout by its subscales. For the emotional exhaustion dimension, the study showed that $25.4 \%$ and $31.7 \%$ of the nurses had moderate and high emotional exhaustion levels respectively. In contrast with these findings, a crosssectional conducted among Lebanese nurses reported $77.5 \%$ of the nurses have high level of EE (30); whereas in consistent with the present study finding, another cross-sectional survey was carried out in Lebanese nurses revealed high EE in $23.2 \%$ of the studied nurses. ${ }^{31}$ In Western countries, high levels of EE were reported as well among mental health nurses. In their survey carried out with 614 community mental health nurses in Wales, UK, Hannigan et al. ${ }^{32}$ reported that half of the studied sample was emotionally exhausted by their work. As regards factors associated with $\mathrm{EE}$, an Iranian study showed significant positive correlation between age, work experience, on-call duties, and EE for the nurses working in psychiatric care. Frequency of on-calls was also significantly associated with a sense of declined accomplishment. ${ }^{33}$

In Alkhobar, Saudi Arabia, the prevalence of BS among multinational nurses at King Fahd University Hospital was concluded to be high. High frequency of EE (45\%) among the national and expatriate nurses. Also, Married nurses found to be more 
prone to EE than unmarried ones $(28.17 \pm$ 12.1 versus $22.3 \pm 9.6$ respectively, $\mathrm{P}$ $0.003)$. Non-Saudi nurses have reported significantly higher EE than Saudis (27.3

Table 3 Association of socio-demographic and work-related factors with $\mathrm{EE}$ dimension of burnout syndrome among the participants $(\mathrm{N}=142)$

\begin{tabular}{|c|c|c|c|c|c|}
\hline Factors & $\begin{array}{c}\text { No } \\
\text { n }(\%)\end{array}$ & $\begin{array}{c}\text { Yes } \\
\text { n }(\%) \\
\end{array}$ & OR & $95 \%$ CI & $P$ value \\
\hline $\begin{array}{l}\text { Gender } \\
\text { Male } \\
\text { Female }\end{array}$ & $\begin{array}{l}48(49.0) \\
13(29.5)\end{array}$ & $\begin{array}{l}50(51.0) \\
31(70.5)\end{array}$ & 0.43 & $0.20-0.93$ & $0.031^{*}$ \\
\hline $\begin{array}{l}\text { Nationality } \\
\text { Saudi } \\
\text { Non-Saudi }\end{array}$ & $\begin{array}{r}54(41.9) \\
7(53.8) \\
\end{array}$ & $\begin{array}{r}75(58.1) \\
6(46.2) \\
\end{array}$ & 1.62 & $0.51-5.09$ & 0.405 \\
\hline $\begin{array}{l}\text { Having children } \\
\text { Yes } \\
\text { No }\end{array}$ & $\begin{array}{l}48(45.3) \\
13(36.1)\end{array}$ & $\begin{array}{l}58(54.7) \\
23(63.9)\end{array}$ & 0.68 & $0.31-1.40$ & 0.337 \\
\hline $\begin{array}{l}\text { Job title } \\
\text { Nurse } \\
\text { Nurse assistants }\end{array}$ & $\begin{array}{r}59(43.1) \\
2(40.0) \\
\end{array}$ & $\begin{array}{r}78(56.9) \\
3(60.0) \\
\end{array}$ & 0.88 & $0.14-5.44$ & 1.00 \\
\hline $\begin{array}{l}\text { Current working hours } \\
\leq 8 \text { hours } \\
>8 \text { hours }\end{array}$ & $\begin{array}{l}31(44.3) \\
30(41.7)\end{array}$ & $\begin{array}{l}39(55.7) \\
42(58.3)\end{array}$ & 0.89 & $0.46-1.74$ & 0.753 \\
\hline $\begin{array}{l}\text { Currently working during } \\
\text { night shifts } \\
\text { Yes } \\
\text { No }\end{array}$ & $\begin{array}{r}27(37) \\
34(49.3) \\
\end{array}$ & $\begin{array}{r}46(63) \\
35(50.7) \\
\end{array}$ & 1.65 & $0.84-3.23$ & 0.139 \\
\hline $\begin{array}{l}\text { Currently working during } \\
\text { weekends } \\
\text { Yes } \\
\text { No }\end{array}$ & $\begin{array}{l}32(38.6) \\
29(49.2)\end{array}$ & $\begin{array}{l}51(61.4) \\
30(50.8)\end{array}$ & 1.54 & $0.78-3.06$ & 0.209 \\
\hline
\end{tabular}

${ }^{*} p<0.05$ is statistically significant

expatriate nurses. ${ }^{6}$ In our study, examining the factors associated with EE revealed that male nurses were less likely to have emotional exhaustion compared to female nurses $(\mathrm{OR}=0.437,95 \% \mathrm{CI}=0.204$ $-0.933, \mathrm{p}=0.031$ ).

Low level of depersonalization (DP) was found in about $70 \%$ of nurses in the present study, whereas high and moderate levels were found in $15.5 \%$ and $14.1 \%$ of them respectively. High level DP was as well reported to be $70.7 \%$ in one study ${ }^{31}$ compared to the finding reported in other two studies $47.1 \%{ }^{34}$ and $36.0 \% .^{30}$ Similarly, two studies including physicians were conducted including physicians in Egypt reported high level of DP. ${ }^{35,36}$ Prevalence for high burnout in Saudi Arabia showed similar variability in \pm 12.1 versus $21.6 \pm 2.9$ respectively, $\mathrm{P}=0.004)$. Working away from their home countries was an additional risk factor in 
shifts pattern were associated with higher levels of DP among nurses. ${ }^{30}$

The present study has also examined the level of personal accomplishment (PA) in the studied nurses and revealed high level of PA among $46.5 \%$ of them. Moderate and low levels of PA, however, were found in $15.5 \%$ and $38 \%$, respectively. Similarly, the level of PA was low in Arab countries, including Jordan ${ }^{16}$ and

Table 4 Association of socio-demographic and work-related factors with DP scale among the participants $(\mathrm{N}=142)$

\begin{tabular}{|c|c|c|c|c|c|}
\hline Factors & $\begin{array}{c}\text { No } \\
\text { n }(\%)\end{array}$ & $\begin{array}{c}\text { Yes } \\
\text { n }(\%)\end{array}$ & OR & $95 \% \mathrm{CI}$ & $P$ value \\
\hline $\begin{array}{l}\text { Gender } \\
\text { Male } \\
\text { Female }\end{array}$ & $\begin{array}{l}68(69.4) \\
32(72.7)\end{array}$ & $\begin{array}{l}30(30.6) \\
12(27.3)\end{array}$ & 1.176 & $0.53-2.59$ & 0.687 \\
\hline $\begin{array}{l}\text { Nationality } \\
\text { Saudi } \\
\text { Non-Saudi }\end{array}$ & $\begin{array}{l}60(69.0) \\
11(84.6) \\
\end{array}$ & $\begin{array}{r}40(31.0) \\
2(15.4) \\
\end{array}$ & 2.472 & $0.52-11.6$ & 0.345 \\
\hline $\begin{array}{l}\text { Having children } \\
\text { Yes } \\
\text { No } \\
\end{array}$ & $\begin{array}{l}76(71.7) \\
24(66.7) \\
\end{array}$ & $\begin{array}{l}30(28.3) \\
12(33.3) \\
\end{array}$ & 0.789 & $0.35-1.77$ & 0.568 \\
\hline $\begin{array}{l}\text { Job title } \\
\text { Nurse } \\
\text { Nurse assistants }\end{array}$ & $\begin{array}{r}96(70.1) \\
4(80.0) \\
\end{array}$ & $\begin{array}{r}41(29.9) \\
1(20.0) \\
\end{array}$ & 1.708 & $0.18-15.75$ & 1.00 \\
\hline $\begin{array}{l}\text { Current working hours } \\
\leq 8 \text { hours } \\
>8 \text { hours }\end{array}$ & $\begin{array}{l}51(72.9) \\
49(68.1) \\
\end{array}$ & $\begin{array}{l}19(27.1) \\
23(31.9) \\
\end{array}$ & 0.794 & $0.38-1.63$ & 0.531 \\
\hline $\begin{array}{l}\text { Currently working } \\
\text { during night shifts } \\
\text { Yes } \\
\text { No }\end{array}$ & $\begin{array}{l}52(71.2) \\
48(69.6)\end{array}$ & $\begin{array}{l}21(28.8) \\
21(30.4)\end{array}$ & 0.923 & $0.44-1.89$ & 0.828 \\
\hline $\begin{array}{l}\text { Currently working } \\
\text { during weekends } \\
\text { Yes } \\
\text { No }\end{array}$ & $\begin{array}{l}59(71.1) \\
41(69.5)\end{array}$ & $\begin{array}{l}24(28.9) \\
18(30.5)\end{array}$ & 0.927 & $0.44-1.92$ & 0.838 \\
\hline
\end{tabular}

Table 5 Association of socio-demographic and work-related factors with PA scale among the participants $(\mathrm{N}=142)$

\begin{tabular}{|c|c|c|c|c|c|}
\hline Factors & $\begin{array}{c}\text { No } \\
\text { n }(\%)\end{array}$ & $\begin{array}{c}\text { Yes } \\
\text { n }(\%)\end{array}$ & OR & $95 \% \mathrm{CI}$ & $P$ value \\
\hline $\begin{array}{l}\text { Gender } \\
\text { Male } \\
\text { Female }\end{array}$ & $\begin{array}{l}51(52.0) \\
25(56.8)\end{array}$ & $\begin{array}{l}47(48.0) \\
19(43.2)\end{array}$ & 0.825 & $0.40-1.68$ & 0.598 \\
\hline $\begin{array}{l}\text { Nationality } \\
\text { Saudi } \\
\text { Non-Saudi }\end{array}$ & $\begin{array}{r}71(55) \\
5(38.5)\end{array}$ & $\begin{array}{r}58(45.0) \\
8(61.5) \\
\end{array}$ & 1.959 & $0.60-6.31$ & 0.253 \\
\hline $\begin{array}{l}\text { Having children } \\
\text { Yes } \\
\text { No } \\
\end{array}$ & $\begin{array}{l}56(52.8) \\
20(55.6) \\
\end{array}$ & $\begin{array}{l}50(47.2) \\
16(44.4) \\
\end{array}$ & 0.896 & $0.41-1.91$ & 0.777 \\
\hline $\begin{array}{l}\text { Job title } \\
\text { Nurse } \\
\text { Nurse assistants }\end{array}$ & $\begin{array}{r}72(52.6) \\
4(80.0)\end{array}$ & $\begin{array}{r}65(47.4) \\
1(20.0)\end{array}$ & 0.277 & $0.03-2.54$ & 0.372 \\
\hline $\begin{array}{l}\text { Current working hours } \\
\leq 8 \text { hours }\end{array}$ & $45(64.2)$ & $25(35.7)$ & 2.38 & $0.21-0.82$ & $0.011 *$ \\
\hline
\end{tabular}

\begin{tabular}{lllll}
\hline The Egyptian Journal of Community Medicine & Vol. 39 & No. 3 & July & 2021
\end{tabular}




\begin{tabular}{lccccc}
\hline$>8$ hours & $31(43.1)$ & $41(56.1)$ & & & \\
\hline $\begin{array}{l}\text { Currently working } \\
\text { during night shifts }\end{array}$ & & & & & \\
Yes & $38(52.1)$ & $35(47.9)$ & 0.88 & $0.45-1.71$ & 0.71 \\
No & $38(53.1)$ & $31(44.9)$ & & & \\
\hline $\begin{array}{l}\text { Currently working } \\
\text { during weekends }\end{array}$ & & & & & \\
$\begin{array}{l}\text { Yes } \\
\text { No }\end{array}$ & $42(50.6)$ & $41(49.4)$ & 0.75 & $0.38-1.47$ & 0.408 \\
\hline
\end{tabular}

${ }^{*} p<0.05$ is statistically significant

Lebanon $^{30}$ among nurses. Compared with these findings, however, low level PA was highly reported in some Western studies. In England, the low level of PA among the studied mental health nurses was $60 \% .^{40}$ In Japan, the level of low PA was as high as $72 \%$ among psychiatrists. ${ }^{41}$ In Poland, low PA was reported to be among $77 \%$ of the studied hospital nurses. ${ }^{42}$ Other studies, however, have reported low frequency of low PA; among 10\% in the USA $^{43}$ and $33 \%$ in Scotland. ${ }^{44}$ The discrepancies in these studies, however, could be attributed to the type of the studied population, assessment tools, sample size and technique and the difference in culture among different world countries.

The study presents the level of burnout syndrome by its dimensions (EE, DP and PA). According to our knowledge, this study is the first to address this topic among mental nurses in Madinah, Saudi Arabia. The study may have some limitations, firstly, it was done in a single center and in only one Saudi region and hence the results may not be generalizable to the entire nursing workforce in mental health care service in Saudi Arabia. The design was cross-sectional; therefore, the causality of association could not be confirmed. Finally, the use of self-report questionnaires posed a risk of measurement error, also non-response found in the study and the nurses who were in vacation or sick leaves may be differed from those who responded.

\section{CONCLUSION}

The current study shows a low to moderate level of self-reported burnout among the studied mental health nurses in Madinah city, Saudi Arabia (moderate level of EE, low level of DP and moderate level of PA). Some factors appeared to pose a higher risk of burnout among nurses. Male sex, working hours seem to be associated with burnout subscales. Identifying those at risk will help practitioners develop coping and wellness programs that might alleviate some of the factors that lead to burnout among health care professionals (HCP). Further studies are needed to assess burnout among different specialties of $\mathrm{HCP}$ and to determine the profile of HCP who are atrisk of burnout and assess whether selfreported burnout fluctuates over time in follow up studies.

\section{References}

1. Maslach C, Leiter MP. Understanding the burnout experience: recent research and its implications for psychiatry. World Psychiatry. 2016 Jun;15(2):103-11. doi: 10.1002/wps.20311

2. Maslach C, Schaufeli WB, Leiter MP. Job Burnout. Annu Rev Psychol. 2001; 52:397422

3. Maslach C, Leiter MP. Understanding Burnout. In: The Handbook of Stress and Health [Internet]. Chichester, UK: John Wiley \& Sons, Ltd; 2017 [cited 2018 Feb 23]. p. 36-56. Available from: http://doi.wiley.com/10.1002/978111899381 1.ch3

4. Elbarazi I, Loney T, Yousef S, Elias A. Prevalence of and factors associated with burnout among health care professionals in Arab countries: a systematic review. BMC 
Health Serv Res [Internet]. 2017 Dec 17 [cited 2018 Jul 31];17(1):491. Available from:

http://bmchealthservres.biomedcentral.com/a rticles/10.1186/s12913-017-2319-8

5. Al-Dubai R, Gopal Rampal K. Prevalence and Associated Factors of Burnout among Doctors in Yemen. J Occup Heal [Internet]. 2010 [cited 2018 Feb 11];52:58-65. Available from: https://doi.org/10.1539/joh.O8030

6. Al-Turki HA, Al-Turki RA, Al-Dardas HA, Al-Gazal MR, Al-Maghrabi GH, AlEnizi $\mathrm{NH}$, et al. Burnout syndrome among multinational nurses working in Saudi Arabia. Ann Afr Med [Internet]. 2010 [cited 2018 Aug 1];9(4):226-9. Available from: http://www.ncbi.nlm.nih.gov/pubmed/20935 422

7. Almalki M, FitzGerald G, Clark M. The nursing profession in Saudi Arabia: an overview. Int Nurs Rev [Internet]. 2011 Sep [cited 2018 Feb 17];58(3):304-11. Available from: $\quad$ http://www.ncbi.nlm.nih.gov/ pubmed/21848775

8. Monsalve-Reyes CS, San Luis-Costas C, Gómez-Urquiza JL, Albendín-García L, Aguayo R, Cañadas-De la Fuente GA. Burnout syndrome and its prevalence in primary care nursing: a systematic review and meta-analysis. BMC Fam Pract [Internet]. 2018 May 10 [cited 2018 Aug 9];19(1):59. Available from: http://www.ncbi.nlm.nih.gov/pubmed/29747 579

9. Cañadas-De la Fuente GA, Vargas C, San Luis C, García I, Cañadas GR, De la Fuente EI. Risk factors and prevalence of burnout syndrome in the nursing profession. Int J Nurs Stud [Internet]. 2015 Jan [cited 2018 Aug 9];52(1):240-9. Available from: http://linkinghub.elsevier.com/retrieve/pii/S0 020748914001710

10. Johnson J, Hall LH, Berzins K, Baker J, Melling K, Thompson C. Mental healthcare staff well-being and burnout: A narrative review of trends, causes, implications, and recommendations for future interventions. Int J Ment Health Nurs [Internet]. 2018 Feb [cited 2018 May 1];27(1):20-32. Available from: $\quad$ http://doi.wiley.com/10.1111/ inm.12416

11. Sahraian A, Fazelzadeh A, Mehdizadeh AR, Toobaee SH. Burnout in hospital nurses: a comparison of internal, surgery, psychiatry and burns wards. Int Nurs Rev [Internet]. 2008 Mar [cited 2018 Jul 31];55(1):62-7. Available from: http://doi.wiley.com/ 10.1111/j.1466-7657.2007.00582.x

12. Imai $\mathrm{H}$. Burnout and work environments of public health nurses involved in mental health care. Occup Environ Med [Internet]. 2004 Sep 1 [cited 2018 Aug 9];61(9):764-8. Available from: http://oem.bmj.com /cgi/doi/10.1136/oem.2003.009134

13. McTiernan K, McDonald N. Occupational stressors, burnout and coping strategies between hospital and community psychiatric nurses in a Dublin region. J Psychiatr Ment Health Nurs [Internet]. 2015 Apr [cited 2018 Jul 30];22(3):208-18. Available from: http://doi.wiley.com/10.1111/jpm.12170 14. Gómez-Urquiza JL, Vargas C, De la Fuente EI, Fernández-Castillo R, Cañadas-De la Fuente GA. Age as a Risk Factor for Burnout Syndrome in Nursing Professionals: A Meta-Analytic Study. Res Nurs Health [Internet]. 2017 Apr [cited 2018 Feb 25];40(2):99-110. Available from: http://doi.wiley.com/10.1002/nur.21774

15. Hall LH, Johnson J, Watt I, Tsipa A, O'Connor DB. Healthcare Staff Wellbeing, Burnout, and Patient Safety: A Systematic Review. Harris F, editor. PLoS One [Internet]. 2016 Jul 8 [cited 2018 Aug 16];11(7):e0159015. Available from: http://dx.plos.org/10.1371/journal.pone.0159 015

16. Hamaideh SH. Burnout, Social Support, and Job Satisfaction among Jordanian Mental Health Nurses. Issues Ment Health Nurs [Internet]. 2011 Mar 2 [cited 2018 Jul 30];32(4):234-42. Available from: http://www.tandfonline.com/doi/full/10.3109 /01612840.2010.546494

17. Fernandes LS, Nitsche MJT, Godoy I de. Association between burnout syndrome, harmful use of alcohol and smoking in nursing in the ICU of a university hospital. Cien Saude Colet [Internet]. 2018 Jan [cited 2018 Aug 16];23(1):203-14. Available from: http://www.ncbi.nlm.nih.gov/pubmed/29267 824

18. Olivares-Faúndez VE, Gil-Monte PR, Figueiredo-Ferraz $\mathrm{H}$. The mediating role of feelings of guilt in the relationship between burnout and the consumption of tobacco and 
alcohol. Jpn Psychol Res [Internet]. 2014 Oct 1 [cited 2017 Aug 16];56(4):340-8. Available from:

\section{/10.1111/jpr.12058}

http://doi.wiley.com

19. Söderström M, Jeding K, Ekstedt M, Perski A, Åkerstedt T. Insufficient sleep predicts clinical burnout. J Occup Health Psychol. 2012; 17(2):175-83.

20. Armon G, Melamed S, Shirom A, Shapira I. Elevated Burnout Predicts the Onset of Musculoskeletal Pain Among Apparently Healthy Employees. J Occup Health Psychol. 2010 Oct;15(4):399-408. doi: 10.1037/a0020726

21. Openepi [Internet]. [cited 2017 May 8]. Available from: http://www.openepi.com /SampleSize/SSPropor.htm. Accessed $\underline{3 / 5 / 2017}$

22. Alharbi J, Wilson R, Woods C, Usher K. The factors influencing burnout and job satisfaction among critical care nurses: a study of Saudi critical care nurses. J Nurs Manag [Internet]. 2016 Sep [cited 2017 May 1];24(6):708-17. Available from: http://doi.wiley.com/10.1111/jonm.12386 23. Maslach C, Jackson SE. The measurement of experienced burnout. J Organ Behav [Internet]. 1981 Apr 1 [cited 2018 Aug 17];2(2):99-113. Available from: http://doi.wiley.com/10.1002/job.403002020 5

24. Maslach C, Jackson SE, Leiter M. Maslach Burnout Inventory Manual. Fourth Edi. Mind Garden, Inc. www.mindgarden.com.; 2016.

25. AlSuliman BK, Hablani MN Al. Burnout among nurses in Tabuk military hospital. Int J Med Sci Public Heal. 2014;3(5):540-6.

26. Yahya Al Zahrani $\mathrm{H}$. Prevalence of burnout among health care staff in Saudi Arabia [Internet]. Vol. 1, International Journal of Neuro \& Psychological Disorders. 2014 [cited $2018 \mathrm{Feb}$ 1]. Available from: www.mcmed.us/journal/ijnpd

27. Maslach C, Jackson SE. The measurement of experienced burnout. J Organ Behav [Internet]. 1981 Apr 1 [cited 2018 Aug 17];2(2):99-113. Available from: http://doi.wiley.com/10.1002/job.403002020 5

28. Zaki SM, Elsayed LA, Ibrahim MM. Factors Contributing to Burnout among Saudi Nurses and their Effect on Patients' Satisfaction at Makkah Al-Mukaramah
Hospitals. Life Sci J [Internet]. 2016 [cited 2018 Aug 1];13(5). Available from: http://www.lifesciencesite.com73online 29. Alharbi J, Wilson R, Woods C, Usher K. The factors influencing burnout and job satisfaction among critical care nurses: a study of Saudi critical care nurses. J Nurs Manag [Internet]. 2016 Sep [cited 2017 May 1];24(6):708-17. Available from: http://doi.wiley.com/10.1111/jonm.12386 30. Sabbah I, Sabbah H, Sabbah S, Akoum H, Droubi N. Burnout among Lebanese nurses: Psychometric properties of the Maslach Burnout Inventory-Human Services Survey (MBI-HSS). 2012 [cited 2018 Jul 31];4(9):644-52. Available from: http://dx.doi.org/10.4236/health.2012.49101 31. Alameddine M, Saleh S, El-Jardali F, Dimassi H, Mourad Y. The retention of health human resources in primary healthcare centers in Lebanon: a national survey. BMC Health Serv Res [Internet]. 2012 Dec 22 [cited 2018 Feb 20];12(1):419. Available from: http://www.ncbi.nlm.nih. gov/pubmed/23173905

32. Hannigan B, Edwards D, Coyle D, Fothergill A, Burnard P. Burnout in community mental health nurses: findings from the all-Wales stress study. J Psychiatr Ment Health Nurs [Internet]. 2000 Apr [cited 2018 Jul 30];7(2):127-34. Available from: http://doi.wiley.com/10.1046/j.1365-

2850.2000.00279.x

33. Yousefy AR, Ghassemi GR. Job burnout in psychiatric and medical nurses in Isfahan, Islamic Republic of Iran. East Mediterr Health J [Internet]. 2006 Sep [cited 2018 Feb 4];12(5):662-9. Available from: http://www.ncbi.nlm.nih.gov/pubmed/17333 807

34. Ashkar K, Romani M, Musharrafieh U, Chaaya M. Prevalence of burnout syndrome among medical residents: experience of a developing country. Postgrad Med J [Internet]. 2010 May 1 [cited 2018 May 20];86(1015):266-71. Available from: http://www.ncbi.nlm.nih.gov/pubmed/20448 222

35. Shams T, El-Masry R. Job Stress and Burnout among Academic Career Anaesthesiologists at an Egyptian University Hospital. Sultan Qaboos Univ Med J [Internet]. 2013 May [cited 2018 May 20];13(2):287-95. Available from: 
http://www.ncbi.nlm.nih.gov/pubmed/23862 036

36. Mohammed KA-M, Ali EG, Yousef IM, Fahmy MT, Haggag WE-L. Burnout and Personality among Egyptian Residents. Arab J Psychiatry [Internet]. 2013 Nov [cited 2018 May 20];24(2):148-60. Available from: http://platform.almanhal.com/CrossRef/Previ ew/?ID=2-38774

37. Al-Sareai NS, Al-Khaldi YM, Mostafa OA, Abdel-Fattah MM. Magnitude and risk factors for burnout among primary health care physicians in Asir Province, Saudi Arabia. East Mediterr Health J [Internet]. 2013 May [cited 2018 May 20];19(5):426-34. Available from: http://www.ncbi.nlm.nih.gov/pubmed/ 24617120

38. Mangoulia P, Koukia E, Alevizopoulos G, Fildissis G, Katostaras T. Prevalence of Secondary Traumatic Stress Among Psychiatric Nurses in Gr1. Mangoulia P, Koukia E, Alevizopoulos G, Fildissis G, Katostaras T. Prevalence of SeconAmong Psychiatric Nurses in Greece. 2015 [cited 2018 Jul 30]; Available from: http://dx.doi.org. 2015 [cited 2018 Jul 30]; Available from: http://dx.doi.org/10.1016 /j.apnu.2015.06.001

39. Karakoc A, Yilmaz M, Alcalar N, Esen B, Kayabasi H, Sit D. Burnout Syndrome Among Hemodialysis and Peritoneal Dialysis Nurses. Iran J Kidney Dis [Internet]. 2016 Nov [cited 2017 Apr 18];10(6):395-404. Available from: http://www.ncbi.nlm. nih.gov/pubmed/27903999

40. Jenkins R, Elliott P. Stressors, burnout and social support: nurses in acute mental health settings. J Adv Nurs [Internet]. 2004 Dec [cited 2017 May 8];48(6):622-31. Available from: http://doi.wiley.com/ 10.1111/j.1365-2648.2004.03240.x

41. Umene-Nakano W, Kato TA, Kikuchi S, Tateno M, Fujisawa D, Hoshuyama T, et al. Nationwide survey of work environment, work-life balance and burnout among psychiatrists in Japan. Hashimoto K, editor. PLoS One [Internet]. 2013 Feb 13 [cited 2018 May 21];8(2):e55189. Available from: http://dx.plos.org/10.1371/journal.pone.0055 189
42. Jaracz K, Górna K, Konieczna J. Burnout, stress and styles of coping among hospital nurses. Rocz Akad Med Bialymst [Internet]. 2005 [cited 2018 Aug 20];50 Suppl 1:216-9. Available from: http://www.ncbi.nlm.nih .gov/pubmed/16119670

43. Hanrahan NP, Aiken LH, McClaine L, Hanlon AL. Relationship between psychiatric nurse work environments and nurse burnout in acute care general hospitals. Issues Ment Health Nurs [Internet]. 2010 Mar [cited 2018 Aug 20];31(3):198-207. Available from: http://www.ncbi.nlm.nih. gov/pubmed/20144031

44. Kilfedder CJ, Power KG, Wells TJ. Burnout in psychiatric nursing. $\mathbf{J}$ Adv Nurs [Internet]. 2001 May 9 [cited 2018 Jul 29];34(3):383-96. Available from: http://doi.wiley.com/10.1046/j.13652648.2001.01769.x 